1984

\title{
The Hidden Constitution: Aboriginal Rights in Canada
}

Brian Slattery

Osgoode Hall Law School of York University, bslattery@osgoode.yorku.ca

Source Publication:

American Journal of Comparative Law. Volume 32, Number 2 (1984), p. 361-391.

Follow this and additional works at: https://digitalcommons.osgoode.yorku.ca/scholarly_works cc) (i) $(9)$

This work is licensed under a Creative Commons Attribution-Noncommercial-No Derivative Works 4.0 License.

Recommended Citation

Slattery, Brian. "The Hidden Constitution: Aboriginal Rights in Canada." American Journal of Comparative Law 32.2 (1984): 361-391.

This Article is brought to you for free and open access by the Faculty Scholarship at Osgoode Digital Commons. It has been accepted for inclusion in Articles \& Book Chapters by an authorized administrator of Osgoode Digital Commons. 
BRIAN SLATTERY

\section{The Hidden Constitution: Aboriginal Rights In}

\section{Canada}

Most countries have a national myth-an account that purports to relate the central events of a country's history in compressed form, that explains how the country has come to be and what it stands for. National myths are useful and perhaps indispensable ways of making the complex past relevant to the perplexing present. They provide the framework for much historical writing, and subtly influence lawyers and judges on constitutional issues. All national myths involve a certain amount of distortion. But some at least have the virtue of broad historical accuracy, roughly depicting the major forces at work. The myth that underlies much legal thinking about the history of Canada lacks that redeeming feature.

It is commonly assumed that North America was juridically a vacant land when first encountered by Europeans. Bit by bit, lands were wrested from the wilderness and settled or exploited under grants from a European monarch, who had obtained complete sovereignty and title to the soil upon discovery. All land rights in 
Canada, other than prescriptive rights, stem directly or indirectly from Crown grants. Our laws, legal institutions, and constitutional arrangements all derive from Europe or were created by European settlers. Our law-making bodies ultimately owe their authority to the British Parliament or the British Crown. There are, in a word, no truly indigenous laws, rights, legislatures, or courts in Canada.

This account has marked shortcomings. North America was not, of course, uninhabited when first explored and settled by Europeans. It was the domain of a variety of independent peoples, who possessed their own territories, laws, and governmental institutions. ${ }^{1}$ These groups often had significant military capabilities, sufficient to make them respected and feared by the settler communities and their parent states. Native Americans were jealous of their independence and quick to avenge intrusions on their lands and offenses against their persons. Unless the aboriginal peoples could be conquered, a hazardous enterprise at best, their cooperation and consent were necessary for sufficient lands to be obtained for white settlement and held in safety. But Indian nations ${ }^{2}$ were not viewed simply as obstacles to European penetration. During the seventeenth and eighteenth centuries in particular, they were valued as trading partners and also as military allies in struggles with rival Christian powers. 
European imperial efforts in America usually proceeded on at least two levels simultaneously. At one level, European states grappled among themselves for exclusive access to the advantages offered by the New World, be these precious minerals, skins and furs, fish, timber, or land for settlement. In the effort to improve their position relative to one another, the colonial powers at times advanced extraordinary claims, and sought to justify them by resort to extraordinary principles. At various points, Papal Bulls, early discoveries or explorations, symbolic acts, or feeble coastal settlements were invoked by European nations to support pretensions to vast territories they neither occupied nor controlled. These claims had little foundation in either fact or reason, and usually met with the scorn of competing European powers, even if the same powers on occasion indulged in similar diplomatic fantasies. As Elizabeth I of England tartly observed to the Spanish Ambassador: to sail to and fro, to build huts, to name a river or a promontory could not confer ownership, since prescription without possession was of no effect. ${ }^{3}$ All that mattered in the final analysis was what a state could gain and hold by force, or coerce its rivals to recognize in a treaty settlement. 4

At another level, European states had to deal with the various native peoples who were the real masters of North America. France 
and England might sign a treaty whereby the lands around Hudson Bay would be left to the British Crown, but this document was of little assistance when it came to influencing, much less controlling, the aboriginal inhabitants. ${ }^{5}$ The imperial powers were thus obliged to maintain extensive sets of diplomatic relations with native American peoples, to enter into alliances, sign treaties, and exchange gifts. ${ }^{6}$ Incoming Europeans often did their best to secure some authority over the indigenous groups they dealt with. However, frequently they were in no position to do this, and it was some time before the situation changed.

Interesting complications resulted from the coexistence and interaction of these two diplomatic spheres. The tendency of many commentators has been to wish the complexities away by focusing on one sphere (usually the inter-European) to the exclusion of the other. This blessedly uncomplicated view can no longer be sustained. Yet if the historical role of native peoples is now widely recognized, it has not yet been accommodated by the standard intellectual framework that influences legal thinking. What we lack is a proper understanding of when and how the native peoples of Canada were won to the allegiance of the Crown, and what effect this process had on their original land rights, customary laws, and systems of government. Did the Crown gain sovereignty 
over Canada with or without the consent of the aboriginal peoples, and on what terms was it achieved? Did native groups come to occupy the same status as other Canadian subjects, or did they hold some special relationship with the Crown? It is a remarkable fact that coherent answers to these questions cannot be found in standard treatises on Canadian constitutional law and history, or even in more specialized works.

The Constitution Act, 1982 invites us to remedy this deficiency.7 Sec. 35 provides:

(1) The existing aboriginal and treaty rights of the aboriginal peoples of Canada are hereby recognized and affirmed.

(2) In this Act, "aboriginal peoples of Canada" includes the Indian, Inuit and Metis peoples of Canada.

This section has a curious past. It was not found in the original draft of the Act, but was inserted, in a slightly different form, upon the unanimous recommendation of the Parliamentary Special Joint Committee on the Constitution after strong representations from native organizations. The government's decision to include the section was treated by all parties as an historic occasion and given wide publicity. So, when the section was later dropped from the draft as the result of the federal-provincial agreement of November 1981, there was a sharp 
reaction among both native and non-native Canadians. Intensive lobbying and public demonstrations led to the section's reinstatement with one change: the word "existing" was added to the phrase "aboriginal and treaty rights." 8 In announcing the new version, the Minister of Justice assured the House of Commons that the amendment did not alter the substance of the provision. 9

Sec. 35 has undergone further discussion since the enactment of the Constitution Act, 1982. Sec. 37 of the Act required that a constitutional conference be called within one year to deal with matters concerning the aboriginal peoples of Canada, including the identification and definition of their rights, and stipulated that representatives of aboriginal Canadians be invited to participate. In March 1983, the First Ministers' Conference on Aboriginal Constitutional Matters met at Ottawa, attended by the Prime Minister of Canada, the provincial Premiers or their delegates, territorial representatives and representatives from four national native organizations. The Conference agreed, in an accord dated 16 March, to make certain changes in the existing provisions, and to meet again within one year. ${ }^{\mathrm{D}}$ Resolutions to effect the proposed changes are now being considered by Parliament and the provincial legislatures, and it seems likely the amending process will be successful. So here I will discuss the constitutional provisions in their 
amended form.

Under the 16 March agreement, two further subsections will be added to sec. $35{ }^{11}$ The first serves to remove doubts as to whether the phrase "treaty rights" in sec. 35(1) covers rights gained under nowexisting and future land claims agreements, a number of which have recently been concluded with native peoples or are in the process of being negotiated. ${ }^{\mathbb{R}}$ The second specifies that the aboriginal and treaty rights referred to in sec. 35(1) are guaranteed equally to male and female persons, thus ensuring sexual equality in access to these rights. ${ }^{\mathcal{B}}$ The recent agreement also proposes to add a new sec. 35.1, requiring that any future amendments to the major constitutional provisions regarding aboriginal peoples will first be discussed at a Conference of First Ministers to which aboriginal representatives will be invited.

These sections make up Part Il of the Constitution Act, 1982, entitled "Rights of the Aboriginal Peoples of Canada." They fall outside the Canadian Charter of Rights and Freedoms, found in Part I of the Act. They are supplemented by a provision located within the Charter proper that serves to shield native rights from the possible adverse effects of other Charter provisions. Sec. 25 states:

The guarantee in this Charter of certain rights and freedoms shall not be construed so as to abrogate or 
derogate from any aboriginal, treaty or other rights or freedoms that pertain to the aboriginal peoples of Canada including

(a) any rights or freedoms that have been recognized by the Royal Proclamation of October 7, 1763; and

(b) any rights or freedoms that may be acquired by the original peoples of Canada by way of land claims settlement.

The 16 March agreement changes the wording in para. (b) of sec. 25 so as to indicate that both past and future land claims agreements are covered. 14 The agreement also adds a new sec. 37.1 requiring that two further First Ministers' Conferences be convened before April 1987 to discuss aboriginal constitutional matters.

The most important of these various provisions is that found in sec. 35(1), which states that the existing aboriginal and treaty rights of the aboriginal peoples of Canada are hereby recognized and affirmed. I will focus exclusively on this provision here, leaving aside a range of issues relating to its companion sections. 15 It will be helpful first to identify the two groups of rights referred to, namely "aboriginal" and "treaty" rights, before considering the precise scope and effect of the provision. 
Sec. 35(1) adopts and confirms the common law doctrine of aboriginal rights. 16 This doctrine holds that the Crown's acquisition of North American territories was governed by a principle of continuity, whereby the property rights, customary laws, and governmental institutions of the native peoples were presumed to survive, so far as this result was compatible with the Crown's ultimate title, and subject to lawful dispositions to the contrary. Aboriginal groups presumptively assumed the status of domestic dependent nations united by special ties to the crown as ultimate sovereign. The U.S. Supreme Court articulated this doctrine in the early cases of Johnson v. M'lntosh (1823)17 and Worcester v. Georgia (1832).18 It has figured prominently in a number of Canadian decisions over the years, and was recently reiterated by the Supreme Court of Canada in Calder v. A.G. of British Columbia (1973). 19

The Quebec case of Connolly v. Woolrich (1867)20 provides an interesting example of the doctrine's operation. There the courts upheld a marriage contracted under Cree customary law between a white man and an Indian woman in the Canadian North-West, even though the same man later married another woman in a Christian ceremony recognized by Quebec law. In attempting to discredit the 
first marriage, the second wife argued, among other things, that English common law had been introduced into the North-West before the marriage took place, thus invalidating Indian custom. In any case, she said, the marriage customs of pagan and uncivilized nations such as the Crees could not be recognized even between the natives themselves, much less between a Christian and a native. These arguments did not persuade the courts. The trial judge noted that the first English and French settlers in the North-West found the country in the possession of numerous and powerful Indian tribes. Even if the settlers brought with them the laws of their mother countries, yet, will it be contended that the territorial rights, political organization such as it was, or the laws and usages of the Indian tribes, were abrogated-that they ceased to exist when these two European nations began to trade with the aboriginal occupants? In my opinion, it is beyond controversy that they did not-that so far from being abolished, they were left in full force, and were not even modified in the slightest degree in regard to the civil rights of the natives. 21

The doctrine of aboriginal rights draws on two main sources, namely French22 and English23 state practice regarding Indian nations from early colonial times, and the Royal Proclamation of 1763. The first subject cannot be pursued here. The second, however, 
deserves more than a passing mention, because it provides essential background for an understanding of sec. 35(1).

The Royal Proclamation of 176324

By 1763, Great Britain's long struggle with France for American empire was over. At the Peace of Paris, France ceded all its remaining territories in Canada to the British Crown, as well as its territories east of the Mississippi River. Britain also obtained Florida from the Spanish Crown, thus completing its claims to the eastern and northern sectors of America.25 Only one area was left to another European power, namely the lands west of the Mississippi that France had relinquished to Spain the previous year.26

These treaties temporarily sorted out the claims of the three main European rivals among themselves. But the French Crown could not give Great Britain what it did not possess itself, namely authority over the native groups inhabiting the ceded territories. These nations were, in many cases, trading partners of the French and sometime military allies. If they were not prepared to accept direct French authority, neither were they willing to accept that France might deposit them in the pocket of the English King.

As the Chippewa leader, Minivavana, told an English trader: Englishman, although you have conquered the French, you have not yet conquered us. We are not your slaves. These 
lakes, these woods and mountains, were left to us by our ancestors. They are our inheritance; and we will part with them to none. 27

A similar viewpoint was expressed by certain Wabash River Indians:

you tell us, that when you Conquered the French, they gave you this Country. That no difference may happen hereafter, we tell you now the French never conquered, neither did they purchase a foot of our Country, nor have [they a right] to give it to you, we gave them liberty to settle for which they always rewarded us and treated us with great Civility. 28 Britain was well aware in 1763 of the precarious nature of its relations with the old Indian allies of France, and the growing dissatisfaction of its own native allies and trading partners. Since midcentury, the British government had been increasingly occupied with Indian affairs, and the war with France had emphasized the importance of native friendship and support. For some time, a plan had been afoot to assure the Indians of the Crown's good intentions by removing a principal cause of Indian discontent-white intrusion on Indian lands. This plan culminated in the publication of a Royal Proclamation on 7 October 1763.29 The interest of the document is not purely historical, for its main terms have never been generally 
repealed in Canada.30 Although it must be read in the light of later developments, it still forms a principal basis for aboriginal land claims in many areas.

The Proclamation is one of those legal instruments that does simple things in complicated ways. The central idea of its Indian provisions is very simple: to ensure that no Indian lands in America are taken by British subjects without native consent. This objective is secured by three main measures: colonial governments are forbidden to grant any unceded Indian lands, British subjects to settle on them, and private individuals to purchase them, with a system of public purchases adopted as the official mode of extinguishing Indian title. The British government was particularly concerned at the prospect of white settlement spreading indiscriminately into the American interior, and so the Proclamation temporarily seals off much of that area to settlers, designating it an exclusive Indian territory. But the document's main measures are not confined to the Indian Territory; they apply throughout British North America.

The Indian provisions of the Proclamation begin with a preamble, where the King explains his basic aims:

And whereas it is just and reasonable, and essential to our Interest and the Security of Our Colonies, that the several Nations or Tribes of Indians, with whom We are connected, 
and who live under Our Protection, should not be molested or disturbed in the Possession of such Parts of Our Dominions and Territories as, not having been ceded to, or purchased by Us, are reserved to them, or any of them, as their Hunting Grounds; . . .

While the King asserts ultimate sovereignty over the Indians, he also acknowledges their semi-autonomous status, describing them as Nations or Tribes "with whom We are connected, and who live under Our Protection." He recognizes that the Indians are entitled to undisturbed possession of the lands reserved to them, and, in an important formula repeated later in the text, defines these reserves as any Indian lands that have not been ceded to or purchased by the Crown. The King claims these lands as part of his dominions, but at the same time recognizes the existence of an Indian interest requiring extinguishment by cession or purchase. In technical terms, the Indian interest constitutes a legal burden on the Crown's ultimate title until surrendered.

In 1763, most of the American territories claimed by Britain were unceded lands held by native peoples. Under the Proclamation, such lands were automatically deemed Indian reserves. Their boundaries were determined negatively by past 
Indian cessions and positively by current Indian possessions. Much of the unorganized American interior was still, of course, unceded. But other unceded lands lay within the undisputed boundaries of existing colonies, including the northern colonies of Rupert's Land, Quebec, Newfoundland, and Nova Scotia, now forming part of Canada.

It is sometimes argued that the Proclamation recognized aboriginal land rights only in the exclusive Indian Territory created in the American hinterland.31 On this supposition, Indian title was not recognized in areas specifically excluded from the Territory, such as the coastal belt east of the Appalachian Mountains, and the colonies of Quebec and Rupert's Land.32 But the text does not support this view. After describing the boundaries of the tenitory, the Proclamation orders the removal of all pers9ns who have settled either within the tenitory "or upon any other Lands, which, not having been ceded to, or purchased by Us, are still reserved to the said Indians as aforesaid" (emphasis added). This provision clearly assumes that unceded Indian lands located outside the Indian Tenitory are reserved for Indian use. The King also forbids colonial Governors to make grants of "any Lands whatever, which, not having been ceded to, or purchased by Us as aforesaid, are reserved to the said Indians, or any of them." The ban 
applies to unceded Indian lands generally, wherever they happen to be located. Finally, the Proclamation provides that no private person shall make any purchases from the Indians "of any Lands reserved to the said Indians, within those Parts of Our Colonies where We have thought proper to allow Settlement," and specifies that if the Indians are ever inclined to dispose of such lands, they shall be purchased for the Crown in a public assembly. Since the provision only applies in areas where settlement was permitted, and the Indian Territory was, for the time being, expressly closed to "any Purchases or Settlements whatever," it could only refer to unceded Indian lands found outside the Territory, in eastern and northern colonies where settlement was still allowed.

In brief, the Proclamation recognized that lands possessed by Indians throughout British territories in America were reserved for their exclusive use, unless previously ceded to the Crown. Prior to a public cession of such lands, they could not be granted away or settled. These provisions applied not only to the Indian Territory, but to the full range of British colonies in North America, no matter how humble or peripheral. In this respect, Rupert's Land, Quebec, Nova Scotia, Newfoundland, the Thirteen Colonies, and the Floridas were brought under a uniform legal regime.33 The Indian Territory was placed in a special position. Whereas in other areas Indian 
lands might still be purchased by public authorities, in the territory such purchases were forbidden altogether for the time being. The idea was to divert the flow of white settlement from the American interior to the northern and southern colonies, which were still relatively sparsely settled. However, the Crown envisaged that in due course parts of the Territory might be opened up, in which case the standard regime governing purchase of Indian lands would take effect.

There has been some controversy whether the Proclamation applied to the far western reaches of the American continent, notably modern British Columbia and the Yukon Territory. ${ }^{34}$ The question has usually been treated as depending on how much territory Great Britain claimed in 1763. Here, the historical evidence indicates that British claims extended indefinitely westward to the Pacific Ocean in latitudes now occupied by Canada. ${ }^{35}$ But a better basis exists for resolving the issue. Many of the Proclamation's provisions are framed in general terms, referring broadly to "Our Dominions and Territories" and "Our Colonies or Plantations in America." Imperial enactments using such terms were normally given a prospective application, so as to apply not only to colonies and territories held when the legislation was enacted but also to those acquired subsequently, 
unless this result was clearly excluded. The purpose of the Proclamation was to supply a uniform set of rules governing Indian lands throughout British territories in North America. There is o reason to think that Indian lands located in territories acquired after 1763 needed less protection than those acquired earlier. It is natural to infer that the Proclamation applied to both. 36

The Proclamation of 1763 has a profound significance for modern Canada. Under its terms, aboriginal peoples held continuing rights to their lands except where these rights have been extinguished by voluntary cession. Treaties of cession have been signed for large parts of Canada, notably in Ontario and the Prairie Provinces. But no such treaties exist for the Atlantic Provinces, and parts of Quebec, British Columbia, the Yukon, and the Northwest Territories, as well for pockets of land elsewhere. Moreover, there is doubt whether Canadian legislatures were competent to override the Proclamation's terms prior to 1931, when the Statute of Westminster was enacted. ${ }^{37}$ So native peoples may today hold subsisting aboriginal rights to large tracts of Canadian land.

The Adaptability of Aboriginal Rights

As noted earlier, the doctrine of aboriginal rights extends not only to property rights but also to customary laws and governmental 
institutions. It is important to understand that the internal development of such rights was not arrested at the time the Crown acquired sovereignty. Rather, these rights retained a certain amount of inherent flexibility, allowing for adaption to new circumstances. So, for example, the customs of a native group were not permanently frozen at the time the Crown first asserted sovereignty, in 1670 , or 1763 , or at some other date. They remained responsive to changes in group behavior and attitudes. Likewise, the right of self-government was not tied down to institutions and arrangements prevailing at some distant historical period. In principle, a native group remained free to adopt new governmental structures.

The position of aboriginal land rights is more complex. As we have seen, the Royal Proclamation of 1763 laid down a uniform legal regime governing native title, whereby native groups were recognized as holding communal rights to their unceded lands, subject only to a restriction of alienation. The same position has been held to obtain in common law. At the communal level, the title was a uniform one, not varying in character from group to group or affected by local native custom. It was the same for a nation of farmers as for a band of hunters. In all cases, it allowed for full possession and use of the land. But within a group, the extent to which a particular sub-group, family, or individual might take advantage of the group's collective title was 
determined by rules particular to the group itself, as dictated by customary law and group organs of self-government. In a nutshell, the rights of the group as against the Crown and other outsiders were governed by uniform rules flowing from the Proclamation and the common law, while the rights of group members inter se were governed by rules peculiar to the individual group. The latter could be altered in the same manner as other group customs, by a general change in attitude and practice, or deliberate amendment by competent bodies.

Aboriginal title imported full rights of possession and use. Native groups were not confined in law to any particular mode of land use, much less to "traditional" uses. An Indian band that originally lived by hunting or fishing might turn to farming when wild game became depleted, or to ranching, lumbering or mining. To hold that native peoples were permanently wedded to certain historical practices would in some cases have been to sentence them to slow starvation; in any case, it would have denied them the right to adapt to new conditions or exploit their lands more productively.

The Proclamation did not establish any boundaries between native groups. In practice, such boundaries tended to fluctuate in response to demographic, economic, or military pressures. It could hardly be held that an Indian band that migrated in search of better 
hunting conditions or security from its enemies forfeited any claim to aboriginal title. So, it was recognized that native peoples were entitled to the unceded lands they actually possessed at any given period. When the Crown wanted to negotiate the sU1Tender of certain lands, it dealt with the people actually controlling them. There was usually no inquiry whether the people had been there from "time immemorial" or the date the Crown first claimed sovereignty. Such an approach would have quickly proved unworkable. Of course, once native lands had been validly ceded by a group holding title to them, they were permanently withdrawn from the pool of lands available for aboriginal possession.

\section{Indian Treaties}

As we have seen, many of the native peoples inhabiting the territories claimed by Great Britain in 1763 were in fact independent; at best they were allies and trading partners of the Crown, at worst declared enemies. In areas remote from the eastern colonies, there were numerous groups that had little if anything to do with the British at all.

The Crown thus faced the task of consolidating its territorial claims by slowly earning the allegiance of the native inhabitants. From time to time, it also needed to obtain Indian lands for settlement, and here the Royal Proclamation required a voluntary 
public cession. The practice of making treaties with the Indians was well adapted to both purposes. It was followed in many British colonies up to Canadian Confederation in 1867 , and continued by the Federal government for many years after that date. 38 Indeed, treaties with native peoples have recently been revived in the shape of land claims agreements. ${ }^{39}$

Indian treaties have taken many forms over the years. Some treaties, usually concluded during the early stages of European contact, were drafted as international pacts, whereby a European state negotiated on equal terms with an Indian group regarding such matters as peace, friendship, trade, and alliance.40 Other agreements, which became more common as European states gained the upper hand, defined the relationship between the Crown and what was described as a dependent, protected, or tributary aboriginal nation, one that in some respects owed allegiance to the Crown, but in other respects remained autonomous.41 Another variety of agreement was more on the style of a voluntary submission, in which the members of an Indian group acknowledged their subordination to the Crown and undertook to behave as good and faithful subjects, in return for the Crown's protection and other advantages.42 These types of agreements all had international or broadly constitutional aspects. 
Others were more mundane. The most common was a simple cession of Indian land to the Crown in return for stated consideration, with no attempt to define the overall position of the Indian signatories vis-a-vis the Crown.43

Many historical agreements were a mixture of types. An example is provided by Treaty Number Three, known as the North-West Angle Treaty, signed in 1873 between the Crown and the Saulteaux Tribe of Ojibway Indians, inhabiting an area now straddling the border of Ontario and Manitoba.44 The Treaty served a number of goals, broadly described in the opening paragraphs as obtaining the Indians' consent to the settlement of their country, and establishing peace and goodwill between them and the Crown. The initial clauses refer to the Indians as subjects of the Queen. But subsequent provisions make it clear that one function of the Treaty is in fact to secure the Indians' formal adherence to the Queen as sovereign. Thus, the Indians promise to conduct themselves as good and loyal subjects of Her Majesty, to obey the law, to maintain peace with both whites and Indians, to refrain from molesting the persons or property of other inhabitants, and to help apprehend any Indians infringing the law or the Treaty provisions.

These were not mere pro forma undertakings. The independent attitude of the Indians is illustrated by the statement of their spokeman, 
Mawedopenais, during negotiations with Crown officials:

We think it a great thing to meet you here. What we have heard yesterday, and as you represented yourself, you said the Queen sent you here, the way we understood you as a representative of the Queen. All this is our property where you have come. . . This is what we think, that the Great Spirit has planted us on this ground where we are, as you were where you came from. We think where we are is our property. I will tell you what he said to us when he planted us here; the rules that we should follow us Indians $\mathrm{He}$ has given us rules that we should follow to govern us rightly. 45

This statement suggests that, from the Indians' perspective, they negotiated the Treaty as autonomous peoples, with their own countries and laws. The undertakings made in the Treaty to adhere to the Queen and her laws represent an important voluntary alteration in their status, if in reality those terms were fully explained to the Indian parties and accepted by them.

The Indians also cede to the Crown "all their rights, titles and privileges" to a defined tract of land. In return, the Crown undertakes to set aside certain lands as Indian reserves, to make annual payments to the Indians, to maintain schools on the reserves, to furnish annual supplies of ammunition and twine, and to bestow other specified benefits. In a clause of great practical 
significance to the Indians, the Crown also agrees that they shall continue to have the right to hunt and fish throughout the lands surrendered, subject to any regulations made by the Government of Canada, and excepting any lands to be taken up for settlement, mining, lumbering, or other purposes.

\section{THE CONSTITUTIONAL GLARANTEE}

We are now better equipped to interpret sec. 35(1) of the Constitution Act, 1982. The section states that "the existing aboriginal and treaty rights of the aboriginal peoples of Canada are hereby recognized and affirmed." A number of difficult questions arise regarding the scope and effect of the provision. These depend in part on the meaning of the word "existing." It can be argued that the word has three distinct effects. First, it restricts sec. 35(1) to rights in existence when the Constitution Act, 1982 came into force, and so excludes rights arising after that date. Second, it ensures that the section only covers rights that already existed under common law, statute, or other legal instrument. Third, it preserves the existing subordination of aboriginal and treaty rights to statute, and prevents the Constitution Act, 1982 from entrenching them. I will consider these arguments separately. 
Does sec. 35(1) apply to any aboriginal or treaty rights that happen to exist from time to time, or is it confined to those existing on the date the Constitution Act, 1982 came into force, on what I shall call the "commencement date"? In other words, does the section establish "floating" categories that attach to any rights meeting the section's description regardless of when they arise, or does it establish "fixed" categories covering a finite body of rights identifiable on the commencement date? On the first view, rights under a treaty signed in 1990 would benefit, while on the second view they would not.

A standard rule of statutory interpretation provides that the law is always speaking and applies to new facts as they arise.46 But this presumption can be overturned by the statute's wording, and arguably the word "existing" has that effect here. Turning to judicial decisions, we find that "existing" has sometimes been held to have a prospective application, but in other cases to mean "existing at the time of enactment," depending on the context. 47 The question comes down to what sec. 35(1) intends to say.

Several factors can be cited in favor of the view that the section refers only to rights identifiable on the commencement date. There is a notable difference in phraseology between sec. 35(1) and the protective provision found in sec. 25 of the Charter.48 The latter 
refers to "any aboriginal, treaty or other rights or freedoms that pertain to the aboriginal peoples of Canada," and does not use the qualifier "existing." The presence of that word in sec. 35(1) arguably intimates that a narrower range of rights is singled out for positive recognition, namely those identifiable on the commencement date. This conclusion is bolstered perhaps by the statement that the rights in question "are hereby recognized and affirmed." The wording suggests a discrete act of recognition, pinpointed in time, rather than a continuing process of recognition. The inference seems stronger, however, in the English version than in the French, where no equivalent for "hereby" appears.49

Standing alone, then, sec. 35(1) might well be interpreted as covering only rights existing on the commencement date. However, this interpretation cannot easily be sustained in the light of sec. 35(3), which states:

For greater certainty, in subsection (1) "treaty rights" includes rights that now exist by way of land claims agreements or may be so acquired.

This provision specifies that the word "treaty" includes land claims agreements of the modern type. It also indicates that sec.35(1) covers rights arising from agreements signed after the commencement date. Rights that "may be ... acquired" under land claims agreements are mentioned along with those that 
"now exist" a clear reference to rights acquired in future. Moreover, sec. 35(3) is presented, not as an exception to the rule laid down in sec. $35(1)$, but as a clarification of that rule, enacted only "for greater certainty." If the partial definition of "treaty rights" given in sec. 35(3) is inserted in sec. 35(1), it specifies in effect that the expression "existing ... treaty rights" includes "existing rights that now exist by way of land claims agreements or may be so acquired." This does not make sense unless the word "existing" means "existing from time to time."

On balance, then, sec. 35(1) is best interpreted as embracing not only aboriginal and treaty rights that existed on the commencement date but also those arising later. So, rights acquired under treaties signed after that date will be covered. A different sort of effect may occur in the case of aboriginal rights. The particular form that such rights assume has in principle always been open to change under the doctrine of aboriginal rights. We saw, for example, that native customary law and governmental institutions were not petrified at the moment the Crown assumed sovereignty, but remained living entities open to development in accordance with group needs. Likewise, while aboriginal land title was uniform at the group level, it flowered into any number of distinct species within native groups, in accordance 
with customary law and rules laid down by communal organs. Such rules were not permanent, but could be altered from time to time. The enactment of sec. 35(1) did not bring to a sudden halt all evolutionary processes in these spheres; to the contrary, it reaffirmed the doctrine allowing for such evolution.

If lights may be added by treaty to those already covered by sec. 35(1), it may be inferred that lights covered there may also be modified or extinguished by the same method, without constitutional amendment. As we will see later, the wording of sec. 35(3) strongly implies that aboriginal land lights may be exchanged for treaty lights through land claims agreements.

The general picture that emerges is this. Any aboriginal and treaty lights that stem from acts or circumstances occuring or existing prior to the commencement date qualify for coverage in sec. 35(1). These lights may be supplemented by means of voluntary agreements ("treaties") signed with the Crown after that date. Rights flowing from such agreements will automatically be captured by sec. 35(1), without need for constitutional amendment. By the same token, lights covered by the section may be diminished by agreement. The latter point will receive fuller treatment later. But for the moment it may be adopted as a working hypothesis. 


\section{The Effect of Recognition}

A: second effect can arguably be attributed to the wording "existing." For a light to qualify under sec. 35(1), it must not only be an "aboriginal" or "treaty" light within the section's meaning, it must also have a sound legal basis apart from the Constitution Act, 1982 itself.

The reasoning in support of this conclusion runs as follows. The section is confined to "existing" lights. But lights are intangibles; their existence cannot be demonstrated in the same way as teacups and toadstools. A light "exists" only to the extent that it can be justified by reference to some sort of normative :framework. The only framework which qualifies for this role is that provided by Canadian law. So, for a light to be an "existing light" within the meaning of sec. 35(1), it must already be recognized in Canadian law, apart from the Constitution Act, 1982.

This requirement, if correct, has several consequences. Sec. 35(1) does not bolster the position of lights whose legal status is otherwise uncertain or defective. Moreover, it cannot heal any blemishes in the legal rights it covers; it takes them as they are, warts and all. In short, the section has no remedial effect in respect to the status or character of the rights it addresses.

However, this interpretation is not wholly convincing. 
Consider the position of a right to an annuity held under an Indian treaty that was signed by the Crown under the royal prerogative but never confirmed by Parliament. Arguably, the right is unenforceable in Canadian law in the absence of Parliamentary approval.50 Assuming this is correct, does it necessarily follow that the right is not an "existing treaty right" within the meaning of sec. 35(1)? It would seem more natural to read the section as referring to rights existing under the terms of the treaty, without reference to the larger question of their status in Canadian law. On this view, one effect of the section is in fact to remedy any imperfections in that status.

So it can be argued that the word "existing" does not require that the rights recognized by sec. 35(1) already have a firm basis in Canadian law. Rather, the phrase "existing aboriginal and treaty rights" can be interpreted as referring to any rights of that description that have not previously been extinguished by acts valid under Canadian law. Which interpretation is right? The issue turns less on a bald exegesis of the word "existing" than on a reasonable reading of the provision as a whole. We are drawn once again to the statement that the rights in question "are hereby recognized and affirmed." These words express the section's main purpose and effect, and supply the key to a balanced 
understanding of its terms.

The phrase "are hereby recognized" can be read in two main ways: it can mean "are hereby acknowledged to be valid or genuine," or simply "are hereby accorded notice or consideration."51 If the second construction is correct, then the Constitution Act, 1982 does no more than "note" the rights in question, which raises the question why it bothers to deal with them at all. It seems more likely that the Act means to acknowledge officially the validity of these rights. In fact, the first meaning is the ordinary legal one. A widely used legal dictionary says that "recognition" is equivalent to "ratification" and "confirmation."52 And a provision stating that courts "shall recognize and take notice of all equitable estates, titles, and rights" has been interpreted judicially as directing courts to give effect to those rights. ${ }^{53}$

A similar choice awaits us in interpreting the phrase "are hereby ... affirmed." It can mean "are hereby confirmed or ratified," or alternatively "are hereby strongly asserted."54 Again, the first sense is the ordinary legal one, as dictionaries testify. .55 Black's, for example, says that "affirm" means to "ratify, make firm, confirm, establish, reassert," and Jowitt's notes, among other things, that where a party to a voidable contract waives his right to avoid it he is said to "affirm" the contract.56 Given the doubts surrounding 
aboriginal and treaty rights, it seems likely that the Constitution Act, 1982 uses "affirm" in its normal legal sense of "confirm" or "ratify."

This conclusion is supported by the French version of sec. 35(1), which has equal authority with the English. It provides that the rights in question are "reconnus et confirmes." Thus, "confirmes" is presented as the equivalent of "affirmed." The choice of words is significant. Le Petit Robert tells us that "confirmer", as used in the present context, means "to render certain; to affirm ... the existence of something."57 Moreover, a standard French-English dictionary supplies only one English meaning for "confirmer," namely "to confirm," and gives as an example the phrase "confirmer un traite," that is, "to ratify a treaty."58 It follows that the phrase "are hereby... affirmed" in sec. 35(1) means "are hereby confirmed"; only then does it have a common core of meaning with the French text.

There are numerous authorities on the juridical meaning of "confirm." They hold in effect that to confirm something is to complete or establish what was previously imperfect or uncertain, or to ratify what was done earlier without authority or insufficiently. $5^{9}$ In particular, it seems that to confirm a document may mean to give it a life that it otherwise lacked, as when an invalid document is confirmed by another document.60 In land law, a "confirmation" is the conveyance of an estate or right in lands or tenements to 
someone who already has possession thereof or some estate therein, whereby avoidable estate is made sure and unavoidable or a particular estate is increased or enlarged.61

These authorities suggest that sec. 35(1) has a broad remedial effect. It addresses itself in part to rights that arguably lacked legal status, or were uncertain or defective in various respects, and recognizes them as legal rights, and not merely moral or political rights, or precarious rights dependent on the will of the Sovereign. It follows that the word "existing" does not confine the section to rights already recognized at law, or prevent it from remedying defects in those rights. There would be little point in recognizing and affirming rights if the effect were restricted in advance to rights that needed no recognition or affirmation. Rather, the word "existing" should be read in the second sense considered above, as meaning "unextinguished" or "subsisting" -thus excluding rights that had been terminated by lawful acts prior to the commencement date, but not requiring that any unextinguished rights have been fully recognized in Canadian law before that date.

One point needs explanation. To say that certain rights are now confirmed as legal rights, or that defects in their legal character are cured does not necessarily mean that such rights are immune to statutory override. It means that they are full- 
fledged legal rights, enforceable in the courts, and secure against possible invasion by executive act under the prerogative. Whether the Constitution Act, 1982 also shields aboriginal and treaty rights from statutes is a distinct question, which I shall now consider.

\section{Entrenchment}

Aboriginal and treaty rights could in principle be modified by the acts of a competent legislature before the Constitution Act, 1982 took effect.62 Has this position now changed? The answer depends in part on sec. 52(1) of the Act. This states:

The Constitution of Canada is the supreme law of Canada, and any law that is inconsistent with the provisions of the Constitution is, to the extent of the inconsistency, of no force or effect.

The term "Constitution of Canada" is defined in sec. 52(2) as including the Constitution Act, 1982. Is a law that infringes a right in sec. 35(1) void for inconsistency with the Constitution of Canada? It will be simpler, in answering this question, to deal first with statutes passed after the commencement date, and then those before that date.

Suppose, in 1990, Parliament enacts a statute expropriating a tract of aboriginal land covered by sec. 35(1). The Constitution Act, 1982 directs the courts to recognize the aboriginal title in question, 
while the statute tells them to disregard it. The courts cannot do both. In the absence of any special factors justifying the expropriation, as discussed later, the constitutional provision must take precedence and nullify the conflicting statute.

Nevertheless, it could be argued that the word "existing" in sec. 35(1) preserves aboriginal and treaty rights in the state they were in at the commencement date, which, in principle, included a subordination to statute. If a legislature was competent to curtail aboriginal and treaty rights before the Constitution Act, 1982 took effect, it is still competent to do so. But we have already seen that the phrase "are hereby recognized and affirmed" gives the section a broad remedial effect, disposing of the notion that it preserves the status quo. Moreover, the argument confuses the section's scope with its legal effect. The fact that the section only covers "existing" rights does not necessarily mean that the Act's effect on these rights is controlled by the law formerly in force. $6^{3}$

Another factor must be considered. Sec. 35(1) can only be amended in accordance with Part V of the Act. Under the ordinary procedure, laid down in sec. 38 , an amendment requires the approval of Parliament and of two-thirds of provincial legislatures accounting for fifty percent of the total population of the provinces. Yet the argument set out above holds, in effect, that sec. 35(1) could be 
eviscerated by an ordinary federal statute stating that "the existing aboriginal and treaty rights of the aboriginal peoples of Canada are hereby extinguished." It seems very unlikely that the amending formula can be circumvented so easily.

This conclusion is supported by the wording of sec. 35(4). It provides:

Notwithstanding any other provision of this Act, the aboriginal and treaty rights referred to in subsection (1) are guaranteed equally to male and female persons.

The word "guaranteed" is significant, because it plainly indicates an intent to entrench. If sec. 35(1) did not guarantee aboriginal and treaty rights at all, what would be the point of stating that it guarantees them equally to both sexes?

I conclude, then, that sec. 35(1) entrenches aboriginal and treaty rights against statutory override.64 But entrenchment does not completely preclude legal limitation of those rights. In determining whether a statute infringes a sec. 35(1) right, the courts will have to define the proper bounds of the right, and here they will be guided in part by standards of reasonableness. Once, however, those reasonable bounds have been determined it will not ordinarily be possible for statutes to overstep them.

The question arises whether this is always true, or whether 
there may not be unusual circumstances in which a protected right, as properly defined, may be overridden by ordinary statute. Imagine that in wartime a particular tract of land is needed for defense installations, and for various good reasons no other tract will do. It happens the land is subject to aboriginal title. May the federal government expropriate the land by simple statute, or must it follow the cumbersome procedure laid down for constitutional amendments? It can be strongly argued that sec. 35(1) is governed by an implicit standard of reasonableness, not only in its definition of the rights recognized, but also in the protection it affords to such rights. If this view is correct, then the government may probably proceed by statute, considering the urgency of its requirements.

The implicit standard postulated here is clearly more demanding than that found in sec. 1of the Constitution Act, 1982, which provides that the Charter of Rights and Freedoms guarantees the rights set out in it "subject only to such reasonable limits prescribed by law as can be demonstrably justified in a free and democratic society." It seems that sec. 35 was placed outside the Charter precisely to put it beyond the reach of sec. 1. Moreover, certain aboriginal and treaty rights need special protection because they are capable of being exhausted. If all aboriginal lands were 
taken, aboriginal land rights would, of course, cease to exist. By contrast, a Charter right such as freedom of speech is capable of infinite renewal.

These considerations suggest that sec. 35(1) erects a high barrier against statutory interference, one that can be surmounted only in emergencies, for pressing public need. So aboriginal and treaty rights are not, in ordinary circumstances, subject to statutory expropriation, even if generous monetary compensation is provided. What the Constitution Act, 1982 guarantees is the right itself, not its supposed monetary equivalent. Had the Act contemplated such a substitution, clear language would have been used.

\section{Prior Statutory Extinguishment}

We have been considering laws passed after the commencement date that violate a sec. 35(1) right. What about laws passed before that date? We saw earlier that the phrase "existing aboriginal and treaty rights" does not cover rights extinguished by legislation or other acts before the commencement date. In principle, then, no conflict can arise between rights "existing" on that date and acts passed before then, because the former are defined and limited by the latter. The real problem is determining whether an act passed before the commencement date actually extinguished the right in 
question.

Treaty rights present particular difficulties. Where, for example, a statute in force on the commencement date was inconsistent with a right conferred by a treaty, and the enacting legislature was competent to modify the treaty, did the treaty right cease to "exist" for purposes of sec. 35(1)? Suppose a nineteenth century Indian treaty guarantees an unrestricted right of :fishing in a certain area, and a federal statute in force on the commencement date restricts :fishing in that area for all persons, including Indians. Clearly, the Indians do not have an unrestricted statutory right to fish. But does their treaty right still exist?

The answer depends on the statute's wording. We must distinguish between a statute that nullifies a treaty right and one that merely fails to implement or observe it. The latter would not relieve the Crown of its obligations under the treaty. Where the statute's wording does not indicate that the treaty was present to the mind of Parliament and consciously repudiated, the treaty promise remains intact, if unfulfilled. Explicit words would seem necessary to release the Crown from promises made to private parties in return for substantial benefits gained at those parties' expense. So, where a statute in force on the commencement date is inconsistent with a treaty promise, but does not explicitly repudiate it, the Constitution 
Act, 1982 arguably affirms the promise and renders the legislation ineffective to that extent.

The distinction is clear in principle, but not always in practice. Some Indian treaties expressly say that certain promises are subject to future governmental regulation. In Treaty Number Three of 1873, discussed earlier,65 the Queen agrees that the Indian parties shall have the right to continue hunting and fishing throughout the lands surrendered in the Treaty, "subject to such regulations as may from time to time by made by her Government of her Dominion of Canada," and saving any tracts taken up for settlement or other purposes. By contrast, certain earlier treaties containing similar promises make no reference to future governmental regulation.66 If sec. 35(1) entrenches the actual rights guaranteed in Indian treaties, what effect does it have on the promise made in Treaty Three?

It could be argued, on the one hand, that the treaty right is explicitly characterized as subject to governmental regulation; so, the constitutional entrenchment of the right does not remove its liability to legislative erosion or extinguishment. On the other hand, it could be said that the treaty simply makes explicit what would in any case be understood: rights are subject to Parliamentary regulation unless specially" entrenched. On this view, since the Constitution Act, 1982 alters the principle of Parliamentary supremacy referred to in the 
treaty, it also places the treaty right beyond legislative interference.

The question boils down to the correct interpretation of the treaty. What does the Crown undertake to do, on a reasonable view of the written text and related negotiations? In 1873, hunting and fishing were the mainstay of many Indian groups. It seems unlikely that the Indians would have agreed that, in return for ceding away most of their lands, they would receive a right of hunting and fishing characterized as liable to complete suppression. On the other hand, the reference to governmental regulation is argt.1ably something more than the expression of a standard constitutional rule. At least in the written text, it seems to qualify the scope of the Crown's undertaking directly.

These reflections suggest a middle road between the two opposing views. What the Crown promises is that the Indians shall have the right to hunt and fish, subject to future regulation as opposed to suppression. That is, the government reserves the power to regulate the manner in which the rights are exercised, short of substantial interference with the right itself. Of course, as a matter of constitutional law, the Crown in Parliament remained free to impose whatever statutes it wished, but, as a matter of treaty, the Crown undertook to confine its interference to mere regulation. If this interpretation is correct, the Constitution Act, 1982 reaffirms the treaty 
promise and nullifies any legislation that crosses the line between regulation and suppression.

\section{Voluntary Extinguishment}

A further question now arises. Can rights governed by sec. 35(1) be modified or extinguished by the voluntary act of the native people concerned without a constitutional amendment? To take a concrete example, can aboriginal land rights be ceded to the Crown by agreement coupled with ordinary legislation, or must an amendment to the Constitution Act, 1982 be secured?

Forceful arguments can be made for the validity of voluntary surrenders, at least in the case of aboriginal land rights. The purpose of sec. 35(1), it can be said, is to insulate the rights of aboriginal peoples from external threat, not to protect native peoples, as it were, from themselves. There is no apparent reason why a total of seven pro"vinces should have to sanction a land claims settlement, as would be required under the amending formula in sec. 38 . Neither would such a requirement better protect the interests of the native peoples themselves. It has always been considered possible for a native people to cede aboriginal lands to the Crown by treaty, and this historical practice is-reflected in the wording of sec. 35(1), with its reference to both aboriginal and treaty rights.

More strikingly, both sec. 25 and sec. 35(3) refer to rights 
acquired under future land claims agreements.67 These references indicate that aboriginal land rights may be voluntarily exchanged for treaty rights, and are not inherently inalienable. They also imply that this exchange can take place without constitutional amendment. Thus, sec. 35(3) provides in effect that where an aboriginal land claim is settled, the agreement will be automatically entrenched in the Constitution. But if rights conferred in return for aboriginal lands are entrenched without constitutional amendment, it follows that the surrender itself may take effect without such amendment. It goes without saying that, for a surrender to be valid, it must be fully voluntary, and that sec. 35(1) harbors rules ensuring this.

CONCLUSION

If we survey the results of our analysis, we are struck by the potential of sec. 35(1) to provide solutions to a number of longstanding problems and grievances. I have argued that the section officially confirms the doctrine of aboriginal rights, whereby the original rights of native American peoples are held to have survived the Crown's acquisition of sovereignty, except insofar as these were incompatible with the Crown's ultimate title, or were subsequently modified by statute or other lawful acts. It also confirms that aboriginal rights are legal rights, maintainable at law as against 
the Crown and private parties. The section likewise recognizes that rights conferred on native peoples in treaties signed by the Crown are enforceable in the courts, regardless whether the treaties were previously confirmed by statute. But the section does not resurrect any aboriginal or treaty rights that had been extinguished by lawful acts before the Constitutional Act, 1982 came into force. Rights covered by the section are shielded against encroachment by ordinary statutes, except perhaps in cases of emergency. Nevertheless, they can be supplemented or diminished by voluntary agreement with the native peoples concerned, without resort to constitutional amendment.

Beyond its practical effect, sec. 35(1) has an important symbolic significance. The Constitution now clearly acknowledges the historical role of native peoples in the making of Canada. That this should rank as an achievement is itself a poignant comment on the modern position of native peoples. It is now over two centuries since the Royal Proclamation of 1763 was issued. The bicentenary of that event passed twenty years ago without a trace of public recognition in Canada. The Constitution Act, 1982 is the measure of how far we have come in the past two decades. Canada now seem poised to reclaim as its own the constitutional structures that developed during almost five centuries of European relations 
with native Canadian peoples. 


\section{ANNEX $p^{8}$ \\ Resolution to Amend the Constitution Act, 1982}

Whereas the Constitution Act, 1982 provides that an amendment to the Constitution of Canada may be made by proclamation issued by the Governor General under the Great Seal of Canada where so authorized by resolutions of the Senate and House of Commons and resolutions of the legislative assemblies as provided for in section 38 thereof;

And Whereas the Constitution of Canada, reflecting the country and Canadian society, continues to develop and strengthen the rights and freedoms that it guarantees;

And Whereas, after a gradual transition of Canada from colonial status to the status of an independent and sovereign state, Canadians have, as of April 17, 1982, full authority to amend their Constitution in Canada;

And Whereas historically and equitably it is fitting that the early exercise of that full authority should relate to the rights and freedoms of the first inhabitants of Canada, the aboriginal peoples;

Now Therefore the (Senate) (House of Commons) (Legislative Assembly) resolves that His Excellency the Governor General be authorized to issue a proclamation under the Great Seal of Canada amending the Constitution of Canada as follows:

Land claims agreements

Aboriginal and treaty rights are guaranteed equally to both sexes

\section{PROCLAMATION AMENDING THE CONSTITUTION OF CANADA}

1. Paragraph 25(b) of the Constitution Act, 1982 is repealed and the following substituted therefor.

"(b) any rights or freedoms that now exist by way of land claims agreements or may be so acquired."

2 Section 35 of the Constitution Act, 1982 is amended by adding thereto the following subsections:

"(3) For greater certainty, in subsection (1) "treaty rights" includes rights that now exist by way of land claims agreements or may be so acquired.

(4) Notwithstanding any other provision of this Act, the aboriginal and treaty rights referred to in subsection (1) are guaranteed equally to male and female persons."

3. The said Act is further amended by adding thereto, immediately after section 35 thereof, the following section: 
Commitment to participation in constitutional conference

Constitutional conferences

Participation of aboriginal peoples

Participation of territories

Subsection 35(1) not a1fected

Repeal of Part IV.1and this section
"35.1 The government of Canada and the provincial governments are committed to the principle that, before any amendment is made to Class 24 of section 91 of the Constitution Act, 1867, to section 25 of this Act or to this Part,

(a) a constitutional conference that includes in its agenda an item relating to the proposed amendment, composed of the Prime Minister of Canada and the first ministers of the provinces, will be convened by the Prime Minister of Canada; and

(b) the Prime Minister of Canada will invite representatives of the aboriginal peoples of Canada to participate in the discussions on that item."

4 The said Act is further amended by adding thereto, immediately after section 37 thereof, the following Part:

\section{'PART IV.1}

\section{CONSTITUTIONAL CONFERENCES}

37.1 (1) In addition to the conference convened in March 1983, at least two constitutional conferences composed of the Prime Minister of Canada and the first ministers of the provinces shall be convened by the Prime Minister of Canada, the first within three years after April 17, 1982 and the second within five years after that date.

(2) Each conference convened under subsection (1) shall have included in its agenda constitutional matters that directly affect the aboriginal peoples of Canada, and the Prime Minister of Canada shall invite representatives of those peoples to participate in the discussions on those matters.

(3) The Prime Minister of Canada shall invite elected representatives of the governments of the Yukon Territory and the Northwest Territories to participate in the discussions on any item on the agenda of a conference convened under subsection (1) that, in the opinion of the Prime Minister, directly affects the Yukon Territory and the Northwest Territories.

(4) Nothing in this section shall be construed so as to derogate from subsection 35(1)."

5. The said Act is further amended by adding thereto, immediately after section 54 thereof, the following section:

"54.1 Part IV.1 and this section are repealed on April 18, 1987." 
6. The said Act is further amended by adding thereto the following section:

References

1161. A reference to the Constitution Act 1867 to 1982 shall be deemed to include a reference to the Constitution Amendment Proclamation, 1983."

Citation 7. This Proclamation may be cited as the Constitution Amendment Proclamation, 1983. 


\section{Notes}

BRIAN SLA'ITERY is Associate Professor of Law, Osgoode Hall Law School, York University. The author would like to express his appreciation to Messrs. Daniel Gormley and Keith Boswell, and Professors Louise Arbour, Paul Emond, and Peter Hogg for their kind assistance in preparing this work. and to the Social Sciences and Humani- ties Research Council of Canada for generous financial support.

1. For standard survey accounts, see e.g. Driver, Indians of North America (2nd ed. 1969); Jenness, The Indians of Canada (6th ed. 1963).

3. Following ordinary legal usage in Canada, I will use the term "Indian" to refer to the full range of native American peoples, including the Inuit or Eskimo peoples. For legal background, see Re Term Indians, (1939) S.C.R. 104 (S.C.C.).

4. Reported in Zouche, Juris et ludicii Fecialis, sive, Juris inter Gentes, II, 80 (Holland, ed.; Brierly, trans., 1911).

5. For the views of European doctrinal writers of the sixteenth to eighteenth centuries on territorial claims based on discovery, symbolic acts, or token possession, see esp.: Victoria, De Indis et De Ivre Belli Relectiones, passim (Nys, ed., Bate, trans., 1917); Gentili, De lure Belli Libri Tres, II, 80-81, 89, 385 (Rolfe, trans., 1933); Grotius, The Freedom of the Seas, passim (Scott, ed., Magoffin, trans., 1916); Grotius, De Jure Belli ac Pacis Libri Tres, II, 191-92, 202-03, 206-07, 550, 667 (Kelsey, trans., 1925); Zouche, supra n. 3, II, 8, 41, 80, 110; Wolff, Jus Gentium Methodo Scientijica Per- tractatum, II, 156-60 (Drake, trans., 1934); Vattel, Le Droit des Gens, III, 37-38, 84-86, 142-43 (Fenwick, trans., 1916). For discussion of the medieval doctrinal background to European legal attitudes regarding Amerindians, see Muldoon, Popes, Lawyers and Infidels: The Church and the NonChristian World, 1250-1550 (1979). The works of Hanke provide an introduction to the sixteenth century Spanish debate regarding America; see, The Spanish Strugglefor Justice in the Conquest of America (1949); and Aristotle and the American Indians (1959). A valuable collection of documents relat- ing to the diplomatic history of America, with excellent commentaries, is found in

Davenport, European Treaties Bearing on the History of the United States and Its Dependencies - . , 4 vols. (1917-37). For varying accounts of European state practice regarding America, compare the following: Goebel, The Struggle for the Falkland Is- lands 47-119 (1927); Juricek, 'English Territorial Claims in North America under Eliz- abeth and the Early Stuarts," 7 Terrae Incognitae 7 (1975); Keller, Lissitzyn, and Mann, Creation of Rights of Sovereignty through Symbolic Acts, 1400-1800 (1938); Lindley, The Acquisition and Government of Backward Territory in International Law 24-44, 129-38 (1926); McDougal, Lasswell, and Vlasic, Law and Public Order in Space 830-44 (1963); Savelle, The Origins of American Diplomacy: The International History of Angloamerica, 1492-1763 (1967); Slattery, "French Claims in North America, 1500-59," 59 Can. Hist. Rev. 139 (1978); von der Heydte, "Discovery, Symbolic Annexa- tion and Virtual Effectiveness in International Law," 29 Am. J. Int. Law 448 (1935). The work by Keller, et al. must be used with caution; the evidence presented is high- ly selective, and many of the authors historical interpretations are doubtful.

6. See Art. 10 of the Treaty of Utrecht, 1713, in Parry (ed.), The Consolidated Treaty Series, XXVII, 475 at 484 (1969- ).

7. See references infra n. 22, 23, 24. 1,2.

8. The Constitution Act, 1982 is set out in English and French in Schedule B of the Canada Act 1982, c.11 (U.K.), which is the formal enacting vehicle. The Constitu- tion Act, 1982 was brought into force by a Proclamation issued by Elizabeth II, as Queen of Canada, on 17 April 1982 under sec. 58 of the Act; Canada Gazette (Part I), VoL 116, No. 17 at 2927-28.

9. For background, see Hogg, Canada Act 1982 Annotated 1-3, 83 (1982); Sanders, "The Rights of the Aboriginal Peoples of Canada," 61Can. Bar. Rev. 314, 315-21 (1983).

10. Mr. Jean Chretien, The Minister of Justice, went on to explain that the word was added at the request of the Alberta government, which wanted to make explicit what was already implicit in the provision. Canada, House of Commons Debates. (Hansard), Tuesday, 24 November 1981, VoL 124, No. 262, 1st Session, 32nd Parlia- ment, pp. 1320313204.

10 1983 Constitutional Accord on Aboriginal Rights, First Ministers' Conference on Aboriginal Constitutional Matters; Document 800 - 17/041, revised; Ottawa, 15-16 March 1983. The accord was signed by representatives of the federal government, nine of the ten provincial governments, the governments of the Yukon Territory and Northwest Territories, and the four participating native organizations, namely the As- sembly of First Nations, the Inuit Committee on National Issues, The Metis National Council and the Native Council of Canada. The government of Qul!bec alone did not sign.

11. The full English text of the resolution embodying the amendments is given in Annex I to this paper. 
12 The new subsection states: "(3) For greater certainty, in subsection (1) 'treaty rights' includes rights that now exist by way of land claims agreements or may be so acquired."

13. "(4) Notwithstanding any other provision of this Act, the aboriginal and treaty rights refeXTed to in subsection (1) are guaranteed equally to male and female persons."

14. The new paragraph reads as follows: "(b) any rights or freedoms that now exist by way of land claims agreements or may be so acquired."

15. For other discussions, see: Lysyk, "The Rights and Freedoms of the Aborigi- nal Peoples of Canada," in Tarnopolsky and Beaudoin (eds.), The Canadian Charter of Rights and Freedoms 467 (1982); Hogg, supra n. 8 at 69, 8183, 84-85; McNeil, "The Constitutional Rights of the Aboriginal Peoples of Canada," 4 S. Ct.L. Rev. 255 (1982);

Sanders, supra n. 8; Slattery, "The Constitutional Guarantee of Aboriginal and Treaty Rights," 8 Queen's L.J. 232 (1982-83). For general background, see: Cumming and Mickenberg (eds.), Native Rights in Canada (2nd ed. 1972); Lysyk, "The Unique Constitutional Position of the Canadian Indian," 45 Can. Bar. Rev. 513 (1967); Lysyk, "Constitutional Developments Relating to Indians and Indian Lands: An Overview," in Special Lectures of the Law Society of Upper Canada, The Constitution and the Fu-ture of Canada 201 (1978); Lysyk, "The Indian Title Question in Canada: An Ap- praisal in the Light of Calder," 51 CfZn. Bar Rev. 450 (1973); Bartlett, "The Indian Act of Canada," 27 Buffalo L. Rev. 581 (1978), reprinted by U. of Sask. Native Law Centre (1980); Morse, Indian Tribal Courts in the United States: A Modelfor Canada? (U. of Sask. Native Law Centre, 1980).

16 For discussion, see Slattery, Ancestral Lands, Alien Laws: Judicial Perspec- tives on Aboriginal Title (U. of Sask. Native Law Centre, 1983).

17. 8 Wheaton 543.

186 Peters 515.

19. 34 D.L.R. (3d) 45 (S.C.C.) esp. at 150.52, 156, 190.203, 208-11. See also St. Cath erine's Milling and Lumber Co. v. The Queen (1885), 10 O.R. 196 (Ont. Ch.); (1886), 13 O.A.R. 48 (Ont. C.A.); (1887), 13 S.C.R. 577 (S.C.C.); (1888), 1 A.C. 46 (P.C.); Hamlet of Baker Lake v. Minister of Indian Affairs and Northern Development, [1980) 1F.C. 518 (F.C.T.D.); Lysyk, "The Indian Title Question in Canada," supra n. 15.

20. 11 L.C. Jur. 197 (Que. S.C.), also reported at 17 R.J.R.Q. 75. The decision was upheld on appeal sub nom. Johnstone v. Connolly (1869), 17 R.J.R.Q. 266, 1R.L.O.S. 253 (Que. Q.B.). The judgments are reproduced in Slattery (ed.), Canadian Native Law Cases, I, 70243 (U. of Sask. Native Law Centre, 1980).

21. 11 L.C. Jur. 197 at 204-05.

22. For French state practice, see: Slattery, The Land Rights of Indigenous Cana- dian Peoples, As Affected by the Crown's Acquisition of Their Territories 70-94 (D. Phil Thesis, Faculty of Law, Oxford University, $1979_{1}$ reprinted by the U. of Sask. Na- tive Law Centre, 1979); and Slattery, 'French Claims in North America, 1500-59", 59 Can. Hist. Rev. B9 (1978).

23. For English state practice prior to the American Revolution, see: Slattery, Land Rights, supra n. 22 at $10-44,95-174$.

24. For detailed discussion, see Slattery, Land Rights, supra n. 22 at 165-349. I,97.

25. Treaty of Paris, 10 February 1763; see text in Shortt and Doughty (eds.), supra n.24,

26. In a secret treaty concluded at Fontainebleau, dated 3 November 1762; text in Parry (ed.), supra n. 5, XLn, 239.

27. Henry, Travels and Adventures in Canada and the Indian Territories between the Years 1760 and 177644 (1809), quoted in Jones, supra n. 23, at 71. The statement was made at the post of Michilimackinac in the fall of 1761, after Quebec and Mon- treal had been taken by English forces.

28. Croghan, "Journals," 11 Illinois Historical Collections 47-48; quoted in Jones, supra n. 23 at 73 . The year was 1765 .

29. The original text of the Proclamation, as entered on the Patent -Roll for the regnal year 4 Geo. III, may be seen in the British Public Record Office: c.6S3693 (back of roll). The most authoritative printed version is that given in Brigham (ed.), British Royal Proclamations Relating to America, 12 Transactions and Collections of the American Antiquarian Society 212 (1911), which is quoted here. This text is transcribed from the broadside printed in London in 1763 by Mark Baskett, King's Printer.

30. The Proclamation was open to repeal by imperial statute; but there is doubt whether it could be repealed by a local Canadian legislature, prior at least to the Statute of Westminster, 1931, which released Canada from the bonds of ordinary imperial acts. In R. v. Secretary of State for Foreign and Commonwealth Affairs, [1982\} 2 All

E.R. 118 (C.A.), at 24, 125, Lord Denning, M.R., said that the Proclamation "was equivalent to an entrenched provision in the constitution of the colonies in North America" and continued to be constitutionally binding on the Dominion and provin- cial 
legislatures even after Confederation. See also R. v. White and Bob (1964), 50 D.L.R.(2d)613 (B.C.C.A.) per Norris J.A. at 662, cited in R. v. Isaac (1975), 13 N.S.R. (2d ) 460 at 485 (N.S.S.C. App. Div.). The question is discussed in Slattery, Land Rights, supra n. 22 at $315-19$.

31. For detailed treatment of this question, see Narvey, supra n. 24; Slattery, Land Rights, supra n. 22 at 217-27, 244-60.

32. The Indian Territory is described as the residue of British territories in North America after certain named areas are excluded. The excluded areas are the colonies of Rupert's Land, Quebec, East Florida, and West Florida, as well as the area east of the Appalachian watershed For discussion, see Slattery, Land Rights, supra n. 22 at 191-203, 268-82.

33. Canadian courts are divided on this point, but the dominant judicial trend favors the view expressed here. See, for example, the following cases regarding the Maritime provinces: Wannan v. Francis (1958), 20 D.L.R. (2d) 627 at 634 (N.B.S.C., Q.B. Div.); R. v. Isaac (1975), 13 N.S.R. (2d) 460 at 478 (N.S.S.C., App. Div.); R. v. Smith (1980), 13 D.L.R. (3d) 522 at 528, 548-50 (F.C.A.). See also Mitchel v. United States, 9 Peters 711 at $748-49$ (1835) (U.S.S.C.); St. Catherine's Milling and Lumber Co. v. The Queen (1888), 14 A.C. 46 at 54 (P.C.). For different views, see Doe d. Burk v. Cormier (1890), 30 N.B.R. 142 at 148 (N.B.S.C.); R. v. Syliboy, [1929) 1D.L.R. 307 at 310 (N.S. Co. Crt.); R. v. Jacques (1978), 34 A.P.R. 576 at 579-80 (N.B.P.C.). The Supreme Court of Canada stated in Sigeareak v. The Queen, (1966\} S.C.R. 645 at 649- 50 that the Proclamation did not apply to Rupert's Land; but that statement should probably be read as referring only to the extent of the Indian territory, from which Rupert's Land was clearly excluded. The Proclamation's land purchase provisions were not at issue. n. 19 .

34. See, e.g, R. v. White and Bob, supra n. 30, Calder v. A.G. of British Columbia, supra

35. See Slattery, Land Rights, supra n. 22 at 175-90.

36. See authorites and discussion in id. at 329-49.

37. See supra n. 30 .

38. Many of these treaties are collected in Indian Treaties and Surrenders, 3 vols. (190512), and Morris, The Treaties of Canada with the Indians of Manitoba and the North-West Territories (1880). For early treaties in the Maritime provinces, see Ham- ilton and Spray (eds.), Source Materials Relating to the New Brunswick Indian (1976). For background to the treaties, see, e.g., Fumoleau, As Long as This Land Shall Last: A History of Treaty 8 and Treaty 11, 187()..1939 (1973); Price (ed.), The Spirit of the Alberta Indian Treaties (1979); Getty and Lussier (eds.),As Long as the Sun Shines and Water Flows (1983).

39. See The James Bay and Northern. Quebec Agreement (Quebec: Editeur officiel du Quebec, 1976), implemented by S.C. 1976-77, c.32, and S.Q. 1976, c. 46.

40. See, e.g., the Articles concluded at Fort Albany between the colony of New York and the Mohawk and Seneca nations on 24-25 September 1664, the first article of which provides that "the Indian Princes above named and their subjects, shall have all such wares and commodities from the English for the future, as heretofore they had from the Dutch"; O'Callaghan (ed.), Documents Relative to the Colonial History of the State of New York, m, 67 (1856-61). The international status and capacity of Indian peoples and others similarly situated, are discussed in: Victoria, supra n. 4, passim; Ayala, De Jure et Ojficiis Bellicis et Disciplina Militari Libri III, Westlake (ed.), Il, 20 (Bate, trans., 1912): Gentili, De Legationibus Libri Tres, II, 90.91 (Laing trans., 1924); Gentili, supra n. 4, Il, 3841; Suarez, Selections.from Three Works, II, 747- 49, 923-27 (Williams, Brown, and Waldron, trans., 1944); Grotius, De Jure Belli, supra

n. 4, II, 550; Grotius, Freedom of the Seas, supra n. 4 at 13; Wolff, supra n. 4, II, 15, 33- 35, 89, 135, 156-60, 327; Vattel, supra n. 4, m,38, 84-86, 126, 131, 133, 142-43.

41. See, e.g., the Treaty of Middle Plantation of 29 May 1677 in Grant and Munro (eds.), Acts of the Privy Council of England: Colonial Series, I, 733 (1908-1912).

42. See, e.g., the Treaty with the Indians of Nova Scotia drawn up at Boston on 15 December 1725, and later ratified at Annapolis Royal, in Indian Treaties and Surrenders, supra n. 38, II, 198-99; discussed in Slattery, Land Rights, supra n. 22 at 139-41.

43. Many examples can be seen in Indian Treaties and Surrenders, supra n. 38.

44. Text in Moms, supra n. 38 at 320.

45. Id. at 59 .

46. See, e.g., sec. 10 of the Interpretation Act, R.S.C. 1970, c. I-23, which provides: "The law shall be considered as always speaking, and whenever a matter or thing is expressed in the present tense, it shall be applied to the circumstances as they arise, so that effect may be given to the enactment and every part thereof according to its true spirit, intent and meaning." Technically, this section does not apply to the Constitution Act, 1982, which is a U.K. statute enacted for Canada; but it can be argued that the section merely expresses a common law rule of construction that would apply here.

47. Rawls (ed.), Bouvier's Law Dictionary, I at 1155 (3rd. rev., 8th ed., 1914) says with regard to "existing": "The force of this word is not necessarily confined to the present. 
Thus a law for regulating 'all existing railroad corporations' extends to such as are incorporated after as well as before its passage, unless exception is provided in their charters ..." (references omitted). Similarly, 35 Corpus Juris Secundum 224 (1960) states: "The word 'existing' has an ordinary meaning of the fact, or state, of being or living, and carries the implication of having existence now. However, the force of this word is not necessarily confined to the present" (footnotes omitted).

48. Text, supra n. 14 .

49. The French text simply states that the rights in question "sont reconnus et confirmes."

50. Under the principle that the Crown cannot legally commit the public purse to expenditures without the sanction of Parliament.

51. See the definitions of "recognize" in Fowler and Fowler (eds.), The Concise Oxford Dictionary of Current English 1033 (5th ed., 1964), and The O:iford English Dictionary, Vm,253, (1933; reissued 1961).

52. Black's Law Dictionary, 1143 (5th ed. 1979).

53. British Pacific Trust Co.v. Baillie (1914), 7 W.W.R. 17 (B.C.S.C.) at 21.

54. See the Concise O:r:ford Dictionary, supra n. 51at 22, and the Oxford English Dictionary, supra n. 51, I, 157.

55. Id.

56. Black's Law Dictionary, supra n. 52 at 55, and Burke (ed.), Jowitt's Dictionary of English Law, I,69 (2nd ed. 1977).

57. Robert, Dictionnaire alphaMtique et analogique de la langue jrarn;aise 363 (rev. ed., 1981): "Rendre certain; affirmer • • • !'existence de (qqch)."

58. Mansion (ed.), Harrap's Standard French and English Dictionary, I, 181 (1961).

59. Black's Law Dictionary, supra n. 52 at 270.

60. James (ed.), Stroud's Judicial Dictionary of Words and Phrases, I, 548 (4th ed, 1971). S.C.).

61. Id. For an illuminating example, see Byers v. Wa-Wa-Ne, 169 P.121 (1917) (Oregon,

62. Except, of course, when those rights were protected by constitutional provisions binding on the legislature in question. For an excellent review of the constitutional terms relating to native rights in Rupert's Land and the old North-Western Territory and the boundaries of those territories, see McNeil, Native Claims in Rupert's Land and the NorthWestern Territory: Canada's Constitutional Obligations (U. of Sask. Native Law Centre, 1982). McNeil, Native Rights and the Boundaries of Rupert's Land and the North. Western Territory (U. of Sask. Native Law Centre, 1982). For the position of the Royal Proclamation of 1763, see supra n. 30 .

63. This conclusion is supported by a series of cases interpreting the effect of provisions in the South African and Australian constitutions that preserve the "existing" rights of certain public servants; see esp. Noble and Barbour v. South African Rail- ways and Harbours, [1922) A.D. 527 (S.Afr. Sup. Crt., App. Div.); Le Leu v. The Commonwealth (1921), 29 C.L.R. 305 at 314-15 (Aust. H.C.); Lucy v. The Commonwealth (1923), 33 C.L.R. 229 at 238, 243-44, 250, 253-54 (Aust. H.C.); Pemberton v. The Commonwealth (1933), 49 C.L.R. 382 at 388-89, 391,392, 397 (Aust. H.C.).

64. See R. v. Secretary of State for Foreign and Commonwealth Affairs, supra n. 30 at 129, where Lord Denning M.R. states: "It seems to me that the Canada Bill itself does all that can be done to protect the rights and freedoms of the aboriginal peoples of Canada. It entrenches them as part of the constitution, so that they cannot be diminished or reduced except by the prescribed procedure and by the prescribed majorities."

65. Text, supra n. 44.

66. See the Robinson Superior Treaty (1850) and the Robinson Huron Treaty

(1850), in Morris, supra n. 38 at 302-03, 30506.

67. See supra n. 12, 14

68. See supra n. 10:11. 